\title{
IMPACT OF GRINDING COCONUT SHELL AND AGGLOMERATION PRESSURE ON QUALITY PARAMETERS OF BRIQUETTE
}

\author{
Krzysztof Dziedzic $^{1}$, Krzysztof Mudryk ${ }^{1}$, Taras Hutsol ${ }^{2}$, Barbara Dziedzic ${ }^{3}$ \\ ${ }^{1}$ University of Agriculture in Krakow, Poland; \\ ${ }^{2}$ State Agrarian and Engineering University in Podilya, Ukraine; \\ ${ }^{3}$ Cracow University of Economic, Poland \\ krzysztof.dziedzic@ur.krakow.pl,krzysztof.mudryk@urk.edu.pl,pro-gp@pdatu.edu.ua, \\ dziedzicbarbaraa@gmail.com
}

\begin{abstract}
In Poland, biomass is still considered as the basic source of renewable energy. Energy from biomass accounts for $15 \%$ of global energy consumption, while in developing countries this share is higher. The main advantage of biomass is lower emissions of sulphur dioxide during combustion compared to fossil fuels. The main sources of biomass for production of low-processed solid biofuels, such as bales or chips and high processed pellets or briquettes, are plantations of energy plants. Energy plant species, possible to use as a raw material for the production of biofuels, are plants characterized by a high annual growth, resistance to diseases and pests, small habitat requirements and adaptation to the Polish climatic conditions. The paper presents the physico-chemical properties of coconut shells in terms of their energetic use. The results obtained are: humidity $(9.4 \%)$, calorific value $\left(17308.68 \mathrm{~J} \cdot \mathrm{g}^{-1}\right)$, low ash content $(0.66 \%)$ and volatile content $(77.7 \%)$ are comparable to those of biofuels available on the market. The work was also carried out to assess the effect of the shredding degree and the applied agglomeration pressure in the briquetting process on the quality characteristics of the obtained briquettes. For briquetting the raw materials the POR ECOMEC Junior Press was used. Tests were conducted for particulate matter on 8 and $12 \mathrm{~mm}$ sieves and for agglomerate pressure of 37 and $47 \mathrm{MPa}$. The obtained results showed that proper granulation of the raw material and application of appropriate agglomeration pressure improve the qualities of the briquettes.
\end{abstract}

Keywords: pressure agglomeration, grinding, durability, briquette.

\section{Introduction}

Biomass is one of the main sources of renewable energy in Poland, and the conversion of any form of biomass into electrical, mechanical or thermal energy is commonly used in power plants and by individual recipients. The term biomass is characterized by a broad definition, which according to the Act of 20 February 2015 of renewable energy sources is understood as a substance of animal or vegetable origin that is biodegradable, comes from residues, waste or agricultural or forestry products, as well as industry dealing with its processing. The definition also covers cereal grains that do not meet the quality requirements in the intervention purchase or are not subject to such a purchase. Biodegradable municipal and industrial waste of animal or vegetable origin, as well as waste generated as a result of water treatment, wastewater treatment or as residue after processing other wastes, have also been classified as biomass.

The biomass potential in Poland is mainly based on biofuels with agricultural origin from the western and northern parts of Poland and biogas from animal waste originating from the northern parts of the country. According to the European Renewable Energy Center, the amount of straw surpluses available for energy use is about 7.84 million tons per year, while the technical potential of wood with its remnants from forests and orchards is 8.81 million tons $[1 ; 2]$.

According to the Central Statistical Office [3], in Poland domestic renewable energy sources were solid biofuels (72.22 \%), liquid fuels $(10.78 \%)$ and wind energy $(10.76 \%)$. The share of other carriers was definitely smaller and closely related to various climatic and geographical conditions as well as real technical potential.It is worth noting that solid biofuels are also a fundamental carrier in the production of heat from RES $(96.42 \%)$ and one of the main in the production of electricity $(39.79 \%)$ in 2015.

Biomass from energy plantations, as well as waste from plant origin can be used in many ways in energy terms. One of the most common methods of biomass processing is its direct combustion in special boilers or co-firing with unconventional energy carriers [4-11].The choice of the appropriate technology for biomass burning is strictly dependent on its parameters (chemical composition, ash content, volatiles, moisture, calorific value) and the form of fuel, in which it was previously processed. There are many installations of different power on the market, and among them two main combustion 
methods should be specified: combustion in bed, layer or stationary pile and combustion of biomass particles suspended or blown directly from the bottom, top or front to the boiler.Fuel can be fed continuously or in the form of disposable portions (non-continuous).In order to burn clean biomass, special boilers and furnaces are most often used, the method of use of which and the efficiency obtained are closely related to the type and quality of the combusted biofuel [12-15].

The pressure agglomeration of plant materials is the process of thickening and consolidating the comminuted raw material under the influence of internal and external forces, the final product of which is agglomerate of a specific geometric form. On the industrial scale, the most common agglomeration methods are granulation and briquetting processes, which are mainly used in the production of industrial fodder, ecological fuel as well as in the chemical, mining or food industry, where they are most often a component of uncomplicated technological lines with low efficiency. However, they are becoming more and more popular in wood and forest plants as well as in farms [16-18].

The purpose of the work was to determine the impact of the degree of coconut shell refinement and agglomeration pressure on the qualitative characteristics of the obtained briquette (specific density, durability).

The scope of the work included acquiring raw material from units dealing in coconut processing. The next step was to conduct research to assess the energy potential of the shell.

\section{Materials and methods}

Coconut palm is a light-loving plant, which requires humidity of 70-89\%, regular rainfall of 75 $100 \mathrm{~cm}$ per year and average daily temperatures of not less than $12{ }^{\circ} \mathrm{C}$ on each day of the year. Low temperatures or no precipitation inhibit plant growth, which in this case does not bear fruit [19]. Coconut palm grows on sandy and salty beaches, which is why it grows mainly on coastal coasts. Its fruit is coconuts weighing about $2.5 \mathrm{~kg}$.

The largest producer of coconut in the production of goods is Philippines, which cover about $40 \%$ of annual production in the world. Coconuts from these regions are mainly exported to the USA. The next country is Indonesia covering over $21 \%$ of world production and India with production at the level of about 0.7 million tons. These countries together with Sri Lanka, Malaysia and New Guinea are the source of coconut in Europe [20].

Annually, about 75 nuts are obtained from coconut palms, which are processed for cosmetic or food purposes.. An innovative product on the Polish market is the production of coconut husk briquettes, which is a waste in the production of cosmetics and food.

The preparation of the analytical sample was carried out in accordance with the instructions contained in the PN-EN 14780: 2011 standard. In order to get acquainted with the energy potential of the shell in the first stage its physical and chemical properties were determined. Then the raw material was processed - crumbled and briquetted, and the resulting product was subjected to a quality assessment.

The research material was ground on two 8 and $12 \mathrm{~mm}$ working sieves to investigate the impact of the raw material fragmentation on the quality of the obtained briquettes in the agglomeration process. To determine the degree of fragmentation, the bulk density and granulometric composition were determined. In order to evaluate the pressure of the agglomeration process, the strength test of briquettes was carried out and their specific density was determined.

The measurements were made according to the diagram presented in Figure 1.

The coconut shell briquetting process was performed using a briquetting press POR ECOMEC model Junior. The product of work is a briquette with a diameter of approx. $50 \mathrm{~mm}$ and a length dependent on the bulk density of the raw material (the smaller it is, the smaller portion of the raw material is fed into the pre-compaction chamber, and the resulting briquette is characterized by smaller length and vice versa).The briquetting machine POR ECOMEC has the possibility of regulating the working pressure in the thickening chamber. When the pressure in the hydraulic system changes, the forces that affect the piston rod change, which also affects the working pressure in the thickening chamber. The hydraulic pressure of the press is regulated by means of a hydraulic regulator and read on the manometer. 


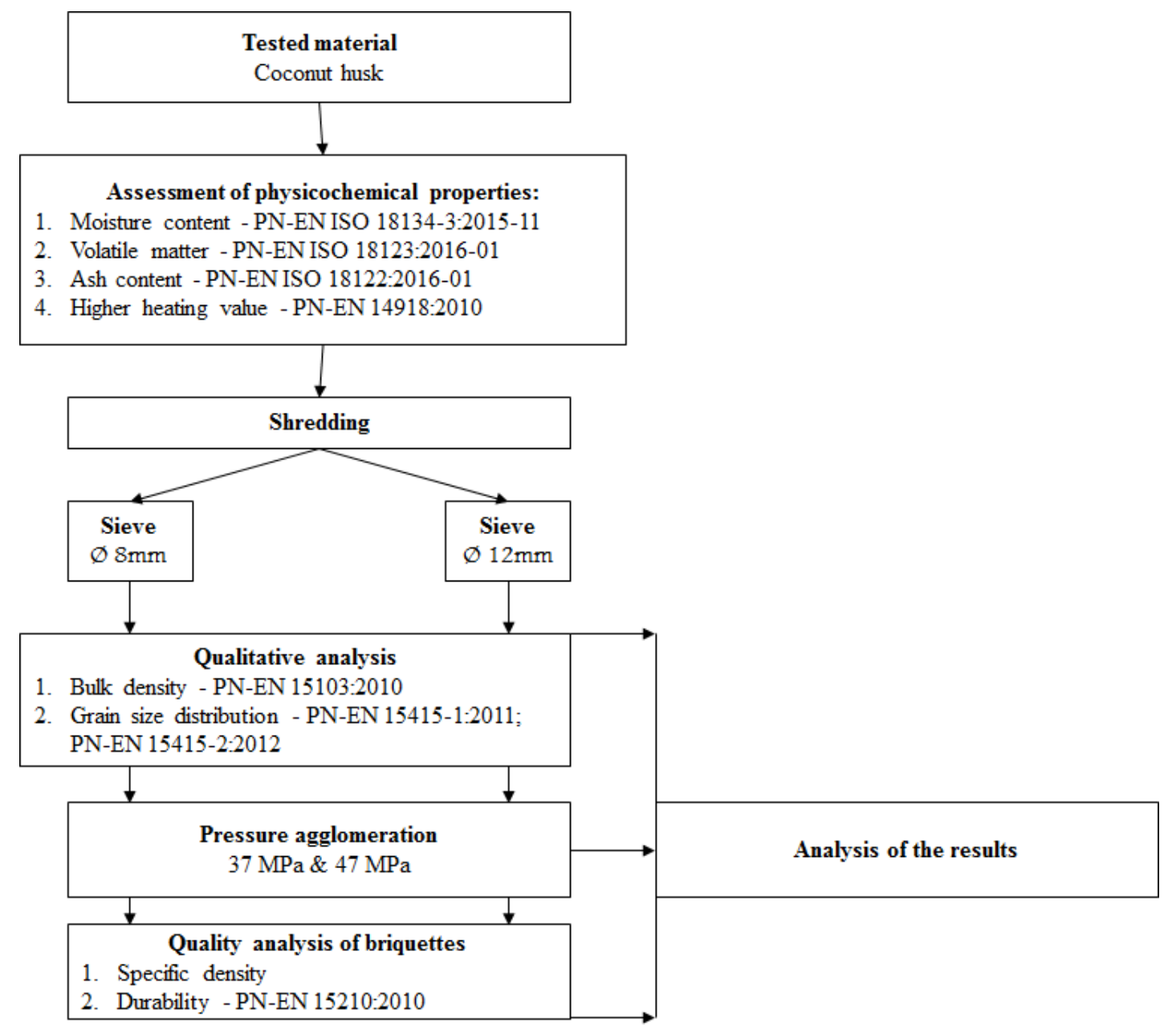

Fig. 1. Research plan

\section{Results and discussion}

Coconut husks have a moisture content of $9.4 \pm 0.9 \%$, which is a permissible value in the standards. This value also does not differ from the classic biofuels available on the market, the maximum moisture content of which is between 17-18\%.

The next parameter was the content of volatile parts. It has a significant impact on the assessment of the usefulness of coconut shells for energy use is at the level of $77.68 \pm 0.59 \%$.

High content of volatile parts in this case may mean that burning the unprocessed shell will result in a large flame and the need to bring an additional amount of air - for smokeless and complete combustion. It is worth emphasizing that this is a characteristic value for plant biomass, for which the content of volatile parts is in the range of $65-80 \%$ [12].

Ash content in the coconut shell did not exceed $1 \%$ and fluctuated within $0.66 \pm 0.109 \%$. This value, compared with the classic solid biofuels, turns out to be one of the lowest, biomass has an ash content of $2 \%$, whereas for agromass it is 4-5\%.The low ash content in the coconut shell turns out to be its great advantage, which increases its attractiveness among typical solid biofuels.

The calorific value and the heat of combustion in the analytical and working state have the same value $-17308.68 \mathrm{~J} \cdot \mathrm{g}^{-1}$ and $18837.00 \mathrm{~J} \cdot \mathrm{g}^{-1}$, respectively. This means that the fuel in the operating condition, which corresponds to the state in which the fuel is extracted, loaded and usable, does not differ from its properties in the analytical state, i.e. in a state of equilibrium with the surrounding atmosphere. It can be treated as an advantage of the shell and considered as a base for comparison with other solid biofuels.

The process of coconut grinding was carried out using two sieves with hole diameters of 8 and $12 \mathrm{~mm}$, respectively. The bulk density tests were carried out for the two fractions of the raw material 
thus obtained and measurement of the granulometric composition. Twice the bulk density measurement for the above mentioned shell fraction in favor of the raw material on a sieve with a diameter of $8 \mathrm{~mm}$ and amounts to $341.5 \pm 4.94 \mathrm{~kg} \cdot \mathrm{m}^{-3}$, or a $12 \mathrm{~mm}$ screen, it is $312.5 \pm 4.24 \mathrm{~kg} \cdot \mathrm{m}^{-3}$. It is also a relatively high value compared to wood chips, the bulk density of which is within limits 250 $280 \mathrm{~kg} \cdot \mathrm{m}^{-3}$.

The measurement of the granulometric composition was based on the use of two sieves with a diameter of 8 and $12 \mathrm{~mm}$. As shown in Figure 2, the largest group (25\%) is crushed raw material in sieves with a hole diameter of $8 \mathrm{~mm}$. The use of sieves with larger diameter holes result in a decrease in the share of the fraction $22 \%$.

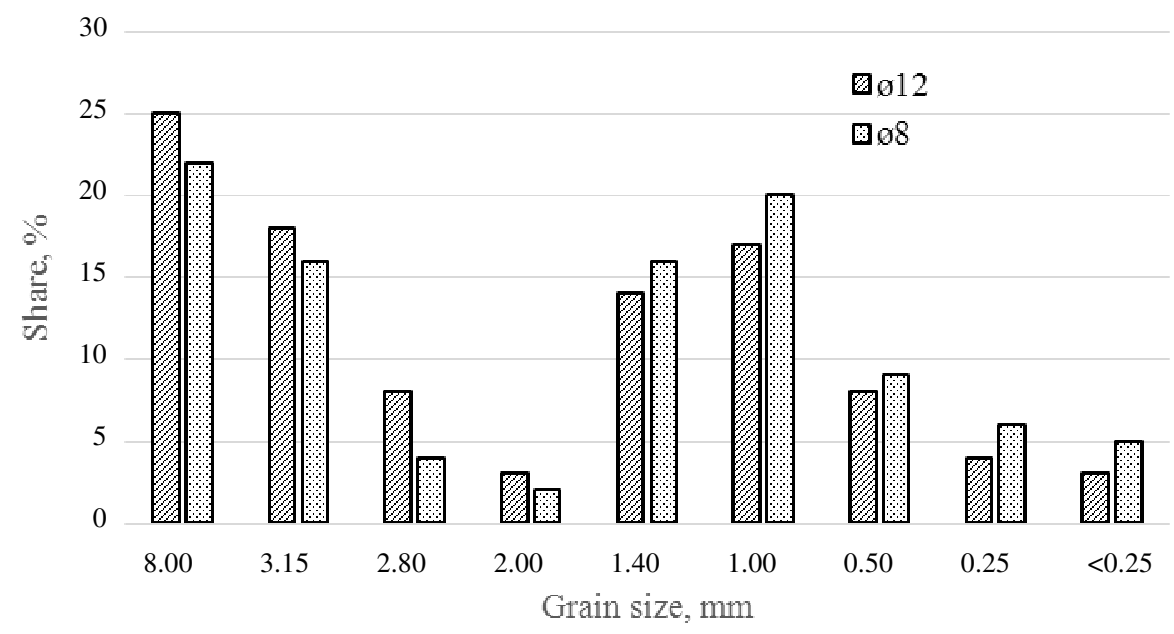

Fig. 2. Grain size distribution of raw material depending on sieve diameter

The mechanical durability of coconut husk varies depending on the agglomeration pressure used and its fragmentation. The best value is represented by fractions with a fragmentation of sieves with a diameter of $8 \mathrm{~mm}$ and a pressing pressure of $47 \mathrm{MPa}$ and amounts to $96.8 \%$. The smallest durability is distinguished by the fraction resulting from cross-cutting on $12 \mathrm{~mm}$ screens and the agglomeration pressure of $37 \mathrm{MPa}$ and is $92.1 \%$. However, this is a satisfactory value comparable with other solid biofuels, for which the mechanical strength oscillates within $95 \%$ for wheat straw also minced on sieves with a diameter of $8 \mathrm{~mm}$ [21-23].

In connection with the above, it can be concluded that a lower degree of fragmentation and a higher pressure of the agglomeration increase the mechanical durability of the shell.

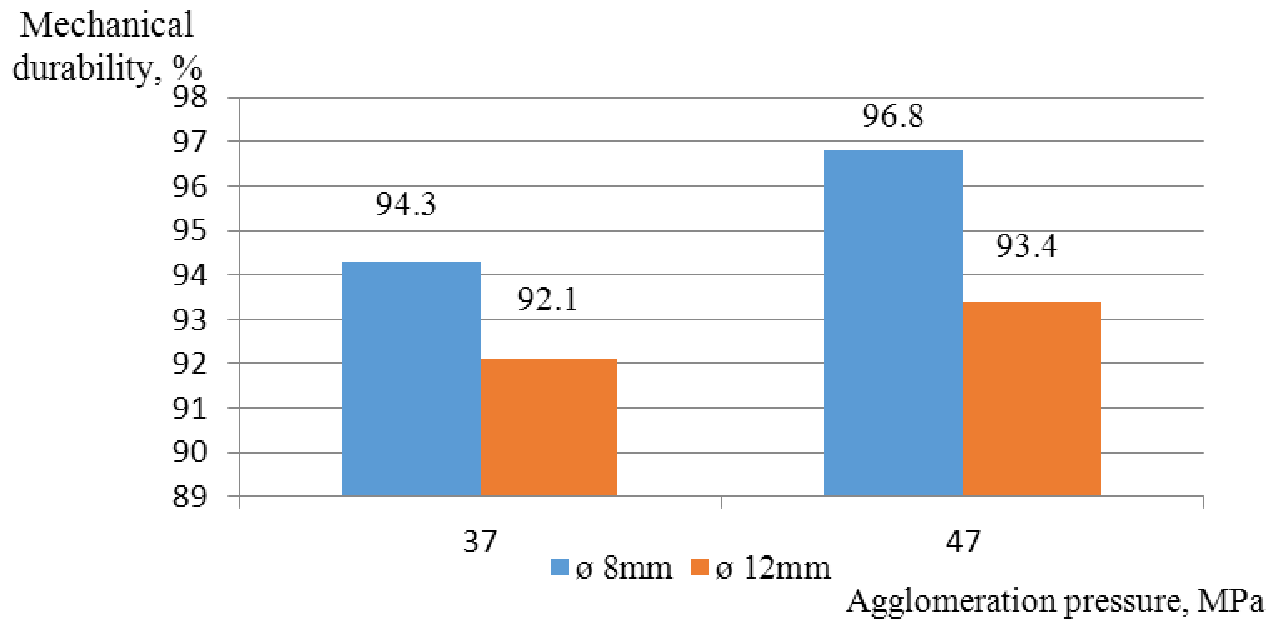

Fig. 3. Mechanical durability depending on sieve diameter

The specific density of the obtained briquettes increases with increasing the agglomeration pressure and a higher degree of shell fragmentation. The largest value, as in the case of mechanical durability, refers to the fraction with fragmentation on sieves with a diameter of $8 \mathrm{~mm}$ and the 
agglomeration pressure of $47 \mathrm{MPa}$ and amounts to $976.4 \mathrm{~kg} \cdot \mathrm{m}^{-3}$. The results referred to the literature data show that the briquettes produced have a relatively good density, which is important in the logistic aspect.

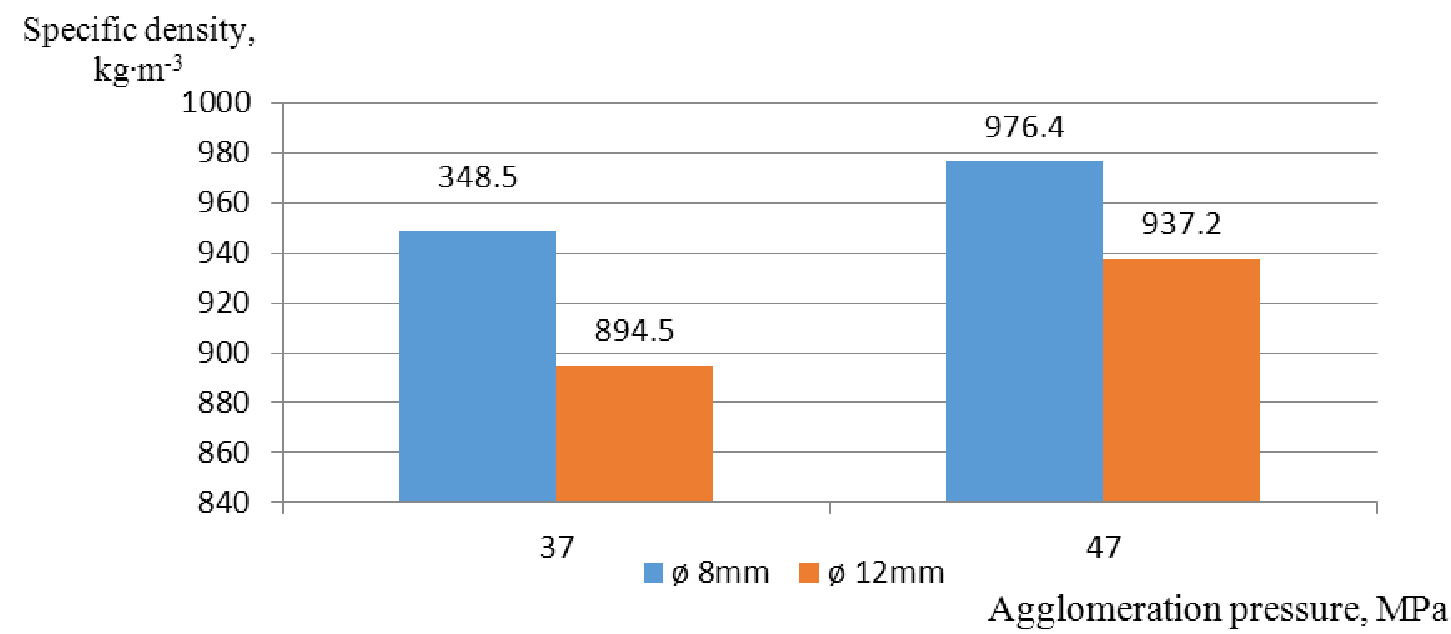

Fig. 4. Specific density depending on sieve diameter

In summary, the resulting granules of coconut shells in the form of briquettes are characterized by good quality. The obtained results indicate that they are similar to the values of classic solid biofuels used for many years on the energy market.

\section{Conclusions}

1. Assessment of the physico-chemical properties of coconut shells allows to state that they can be used for energy purposes. This is supported by the parameters such as: humidity (9.4\%), calorific value $\left(17308.68 \mathrm{~J} \cdot \mathrm{g}^{-1}\right)$, low ash content $(0.66 \%)$ and volatile content $(77.7 \%)$. These values are comparable to the biofuels available on the market.

2. The degree of crumbling of coconut shell and the pressure of agglomeration affect the quality parameters of the obtained briquettes. With greater fragmentation of the raw material and the compaction pressure, the briquette is characterized by better durability and density. The highest mechanical durability $(96.8 \%)$ and specific density $\left(976.4 \mathrm{~kg} \cdot \mathrm{m}^{-3}\right)$ were characterized by ground granulate on sieves with a diameter of $8 \mathrm{~mm}$ using a pressure agglomeration equal to $47 \mathrm{MPa}$, while the worst properties $\left(92.1 \%\right.$ and $\left.894.5 \mathrm{~kg} \cdot \mathrm{m}^{-3}\right)$ occurred in the application of a lower agglomeration pressure (37 MPa) and fragmentation in sieves with a hole diameter of $12 \mathrm{~mm}$.

3. The analysis of the conducted tests allows to conclude that proper preparation of the raw material - crushing coconut shells and applying the appropriate agglomeration pressure may improve the quality parameters of the obtained briquettes.

\section{Acknowledgements}

This Research was financed by the Ministry of Science and Higher Education of the Republic of Poland.

\section{References}

[1] Janowicz L. Biomasa w Polsce (Biomass in Poland). Energetyka, vol. 8, 2006, pp. 601-604. (In Polish)

[2] Niemczyk M., Kaliszewski A., Jewiarz M., Wróbel M., Mudryk K. Productivity and biomass characteristics of selected poplar (Populus spp.) cultivars under the climatic conditions of northern Poland. Biomass and Bioenergy, 2018, vol. 111, pp. 46-51.

[3] Energia ze źródeł odnawialnych w 2015 (Energy from renewable sources in 2015). Główny Urząd Statystyczny. (In Polish).

[4] Kubica K., Jewiarz M., Kubica R., Szlek A. Straw Combustion: Pilot and Laboratory Studies on a Straw-Fired Grate Boiler. Energy \& Fuels, 2016, vol. 30(6), pp. 4405-4410. 
[5] Barnetoa A.G., Carmonaa J.A., Martín Alfonsoa J., Serranob R.S. Simulation of the thermogravimetry analysis of three non-wood pulps. Bioresource Technology, 2010, vol. 101(9), pp. 3220-3229.

[6] Bavutti M., Guidetti L., Allesina G., Libbra A., Muscio A., Pedrazzi S. Thermal stabilization of digesters of biogas plants by means of optimization of the surface radiative properties of the gasometer domes. Energy Procedia, 2014, vol.45, pp. 1344-1353.

[7] Demirbas A. Combustion characteristics of different biomass fuels. Pror. Energy Combust. Sci., 2004, vol. 30, pp. 219-230.

[8] Fagerström J., Steinvall E., Boström D., Boman C. Alkali transformation during single pellet combustion of soft wood and wheat straw. Fuel Processing Technology, 2016, vol. 143, pp. 204212.

[9] Gudde J. Manure digestate combustion for decentralized energy production: research about the feasibility of the manure digestate combustion processing route. Internship Report (Master), Twence B.V. Afvalenenergie, Hengelo, the Netherlands, 2012.

[10] Kihedu J. Torrefaction and Combustion of Ligno-Cellulosic Biomass. Energy Procedia, 2015,vol. 75, pp. 162-167.

[11] Senneca O. Kinetics of pyrolysis, combustion and gasification of three biomass fuels. Fuel Processing Technology, 2007, vol. 88, pp. 87-97.

[12]Rybak W. Spalanie i współspalanie biopaliw stałych (Combustion and co-combustion of solid biofuels). Oficyna Wydawnicza Politechniki Wrocławskiej. ISBN 83-7085-938-0, 2006. (In Polish).

[13]Dubas J., Kotowski W., Tomczyk A. Wierzba energetyczna-uprawa i technologia przetwarzania (Energy-willow-cultivation and processing technology). Bytom: Wydawca Wyzsza Szkola Ekonomii i Administracji w Bytomiu. 3. Eisenbeifi, G, 2004. (In Polish).

[14]Lewandowski W., Radziemska E., Ryms M., Ostrowski P. Nowoczesne metody termochemicznej konwersji biomasy w paliwa gazowe, ciekłe i stałe. Proceedings of ECOpole. 2010, vol. 4(2). (In Polish).

[15] Grabowski Ł., Gliniak M., Wołosiewicz-Głąb M., Dziedzic K. Possibilities of Using the Hydrocarbon Fraction from the Depolymerization Process for Combined Heat and Power Systems. Energy \& Fuels, 2017, vol. 31(3), pp. 2914-2918.

[16] HejftR.,ObidzińskiS. Ciśnieniowa aglomeracja materiałów roślinnych-innowacje technologicznotechniczne (Pressure agglomeration of plant materials - technological and technical innovations Part 1). Część 1. Journal of Research and Applications in Agricultural Engineering, 2012, vol. 57(1), pp.63-65. (In Polish).

[17]Hejft R.,Obidziński S. Ciśnieniowa aglomeracja materiałów roślinnych-innowacje technologiczno-techniczne (Pressure agglomeration of plant materials - technological and technical innovations Part 2). Część 2. Układdozujący, mieszająco-granulujący. Journal of Research and Applications in Agricultural Engineering, 2013, vol. 58(1).(In Polish).

[18] Wrobel M., Frączek J., Francik S., Slipek Z., Mudryk K. Influence of degree of fragmentation on chosen quality parameters of briquette made from biomass of cup plant Silphiumperfoliatum L. In Conference Engineering for Rural Development, Jelgava, Latvia, 2013, pp. 653-657.

[19] Chan E., Craig R. E. Cocos nucifera (coconut) (version 2.1). W: C.R. Elevitch (red.). Species Profiles for Pacific Island Agroforestry. Hōlualoa, Hawai'i: Permanent Agriculture Resources (PAR), 2006.

[20]Falkowski J., Kostrowicki J. Geografia rolnictwa świata (Geography of agriculture in the world). Wydawnictwo Naukowe PWN, Warszawa, 2001. (In Polish).

[21] Hebda T.,Złobecki A. Wpływ stopnia rozdrobnienia słomy na trwałość kinetyczną brykietów (Influence of the degree of straw breaking on kinetic durability of briquettes). Inżynieria Rolnicza, 2012, vol.16, pp. 57-64. (In Polish).

[22] Mudryk K., Frączek J., Wróbel M., Jewiarz M., Dziedzic K. Agglomeration of Ash-Based Fertilizer Mixtures from Biomass Combustion and Digestate. In Renewable Energy Sources: Engineering, Technology, Innovation. Springer, Cham. 2018, pp. 823-834.

[23] Jewiarz M., Frączek J., Mudryk K., Wróbel M., Dziedzic K. Analysis of MSW Potential in Terms of Processing into Granulated Fuels for Power Generation. In Renewable Energy Sources: Engineering, Technology, Innovation. Springer, Cham. 2018, pp. 661-670. 